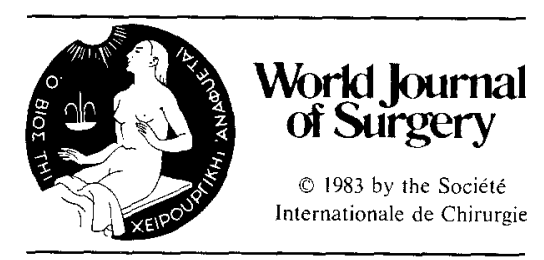

\title{
Fat and Carbohydrate Metabolism During and Following Hemorrhagic Shock in Puppies: A Comparison of Different Resuscitation Protocols
}

\author{
Arnold G. Coran, M.D., and Robert H. Connors, M.D. \\ Section of Pediatric Surgery, Mott Children's Hospital and University of Michigan Medical School, Ann Arbor, Michigan, U.S.A.
}

\begin{abstract}
Shock states continue to carry a high mortality rate in the pediatric age group. Using a puppy model, we measured the initial metabolic response to hemorrhagic shock and to 3 resuscitation regimens: whole blood 1:1 (replacement:shed), lactated Ringer's 3:1, and 5\% albumin in lactated Ringer's 1:1. Despite the immature nature of the puppy's enzyme, cardiovascular, and nervous systems, responses very similar to those in adult animals were seen. Serum glucose and free fatty acids rose during shock and declined with resuscitation as cardiac output returned toward normal. Serum lactate levels rose similarly but continued to rise for a short period after resuscitation and were associated with a further fall in $\mathrm{pH}$ consistent with "hidden acidosis." Only small changes were noted in triglyceride and cholesterol levels. The metabolic responses noted following each of the 3 resuscitation protocols were similar. This study suggests that the immature animal responds to hemorrhagic shock in ways similar to the adult. The better initial hemodynamic response to resuscitation with high-volume lactated Ringer's or lactated Ringer's with $5 \%$ albumin was offset by the better buffering capacity of blood resuscitation. All 3 regimens were equally efficacious in providing initial metabolic recovery in this experimental hemorrhagic shock model.
\end{abstract}

Changes in fat and carbohydrate metabolism are known to be important to the pathophysiology of the shock state. The successful management of shock requires the treatment of both cardiovascular dysfunction and metabolic abnormalities. Shock states of various etiologies continue to carry a high mortality rate in the pediatric age group. Despite this, extensive study of the metabolism of shock in

Reprint requests: Arnold G. Coran, M.D., F7516 Mott Children's Hospital, Box 66, Ann Arbor, Michigan 48109, U.S.A. immature animal models is lacking. Experimental and clinical information is better established for the older organism, but it may not apply to the young animal whose enzyme pathways and cardiovascular and nervous systems are probably immature.

Previous studies in children and young laboratory animals have documented serum levels of glucose [1] and lipids [2, 3] that differ significantly from those of the adult, and have also shown responses to hypoglycemia [4] and ketosis [5] unlike those seen in mature animals. A bradycardic response to hypovolemia, not often seen in adult dogs, has been documented in puppies [6]. To further elucidate the metabolic changes in the immature animal in shock and the response to various resuscitation efforts, we have chosen a puppy model. This study documents the changes in serum-free fatty acids, glucose, triglycerides, lactate, and cholesterol seen during 1 hour of controlled hemorrhagic shock in the puppy and the metabolic recovery achieved with the following 3 resuscitation protocols: replacement with shed blood, replacement $3 \mathrm{ml}$ for $1 \mathrm{ml}$ shed with Ringer's lactate, and replacement $\mathrm{ml}$ for $\mathrm{ml}$ with $5 \%$ albumin in Ringer's lactate.

\section{Materials and Methods}

Eighteen mongrel puppies, each weighing 2-5 kg, were randomly divided into 3 groups. After an overnight fast, each puppy was anesthetized with pentobarbital $(30 \mathrm{mg} / \mathrm{kg})$, intubated, and allowed to respire spontaneously. Bilateral femoral arterial and venous catheterizations were performed and the animal was heparinized (150 U/ $\mathrm{kg}$ beef lung heparin). A Statham $23 \mathrm{db}$ pressure transducer was attached to 1 arterial cannula for continuous monitoring and connected to a Water PRD 15 Physiologi- 
Table 1. Average weight and blood shed. ${ }^{a}$

\begin{tabular}{llll}
\hline & $\mathrm{N}$ & $\begin{array}{l}\text { Weight } \\
(\mathrm{kg})\end{array}$ & $\begin{array}{l}\text { Blood shed } \\
(\mathrm{ml})\end{array}$ \\
\hline Group I & 6 & $2.9 \pm 0.5$ & $100 \pm 29$ \\
Group II & 7 & $3.5 \pm 0.6$ & $139 \pm 29$ \\
Group III & 5 & $3.6 \pm 0.9$ & $128 \pm 37$ \\
\hline
\end{tabular}

aStatistical significance evaluated with Student's $t$-test.

cal Recorder, a multi-channel polygraph and cardiac output recorder. A pediatric thermal dilution cardiac output catheter (American Catheter $5 \mathrm{~F}$ ) was passed via a femoral vein into a pulmonary artery, using pressure tracings to determine the position. The exact location was confirmed at autopsy after the conclusion of the experiment. Routine instrument calibration was done before and after each experiment.

The puppy was allowed to stabilize and 2 baseline determinations were taken 15 min apart. Shock was established by blood withdrawal over 10-15 $\mathrm{min}$ until a stable mean arterial pressure to $50 \mathrm{~mm} \mathrm{Hg}$ was achieved. The shock state was maintained for 1 hour after which the following resuscitation was given: Group I (6 dogs) received shed blood 1:1 (replacement:shed); group II ( 7 dogs) received lactated Ringer's 3:1; and group III (5 dogs) received $5 \%$ albumin in lactated Ringer's 1:1.

Each resuscitation volume was infused intravenously over $15 \mathrm{~min}$ (this corresponds to the $0-15$ min interval under postresuscitation in the figures). At 15-min intervals during both shock and resuscitation, measurements were made of blood pressure, heart rate, cardiac output, hemoglobin, $\mathrm{pH}$, lactate [7], glucose [8], triglycerides [9], cholesterol [10], and free fatty acids [11].

The mean and standard deviations were calculated for each measurement and the results were compared using the Student's $t$-test with $p \leq 0.05$ considered significant.

\section{Results}

Table 1 summarizes measurements of weight and the amount of blood shed in each group. These were the average volumes shed to maintain shock at 50 $\mathrm{mm} \mathrm{Hg}$ and equal approximately $45 \%$ of the animal's estimated blood volume. There were no significant differences seen among the 3 groups. During the baseline period before hemorrhage, no statistical differences were noted in any of the measured parameters $(p<0.05)$. All the puppies survived during the postresuscitation observation period of 1 hour.

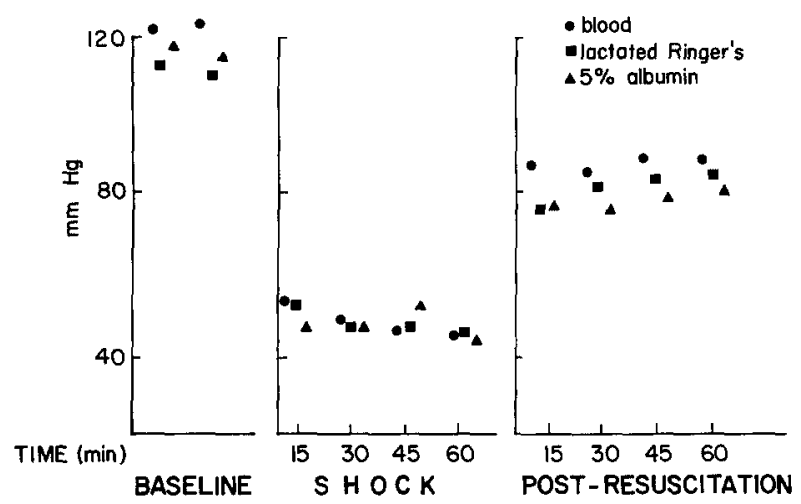

Fig. 1. Mean arterial pressure in 3 groups of puppies undergoing experimental resuscitation for shock.

\section{Hemodynamic Studies}

The fall in mean arterial pressure to $50 \mathrm{~mm} \mathrm{Hg}$ (Fig. 1) was accompanied by a decrease in cardiac output to approximately $50 \%$ of control values (Fig. 2). With resuscitation, the cardiac output in group I returned to preshock levels, while the animals in groups II and III attained greater than baseline cardiac outputs. The early postresuscitation cardiac outputs in groups II and III were significantly greater than those observed in group I, but not different from each other. By the end of 1 hour, outputs in groups II and III were still greater than those in group I, but the differences were no longer statistically significant. Mean blood pressure rose significantly in each group after resuscitation $(p<$ 0.05 ), but did not attain preshock levels.

Bradycardia developed with the onset of shock, but the heart rate gradually increased toward baseline levels $30 \mathrm{~min}$ after the onset of shock and following each of the 3 resuscitation programs (Fig. 3).

Hemoglobin levels were statistically unchanged throughout the experiment in group I, in which shed blood was infused, but fell to half the control values in groups II and III following infusion of resuscitation fluid (Table 2).

\section{Metabolic Studies}

A rapid rise in serum lactate (Fig. 4) was noted after hemorrhage and persisted until 15 min after resuscitation. The measured values then began to decrease, but they never returned to baseline levels. The increase within each group was significant and there was no difference among groups in the pattern of change or the levels of serum lactate despite different resuscitation protocols.

A corresponding fall in bicarbonate $(p<0.05)$ (Table 3), and in $\mathrm{pH}$ to less than $7.1(p<0.05)$ 


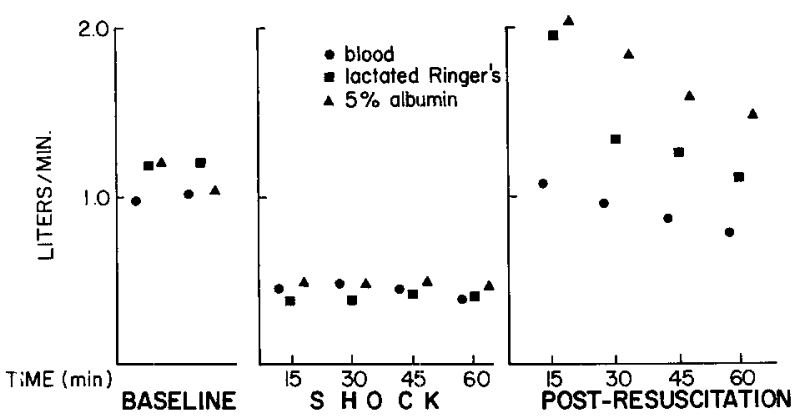

Fig. 2. Cardiac output in 3 groups of puppies undergoing experimental resuscitation for shock.

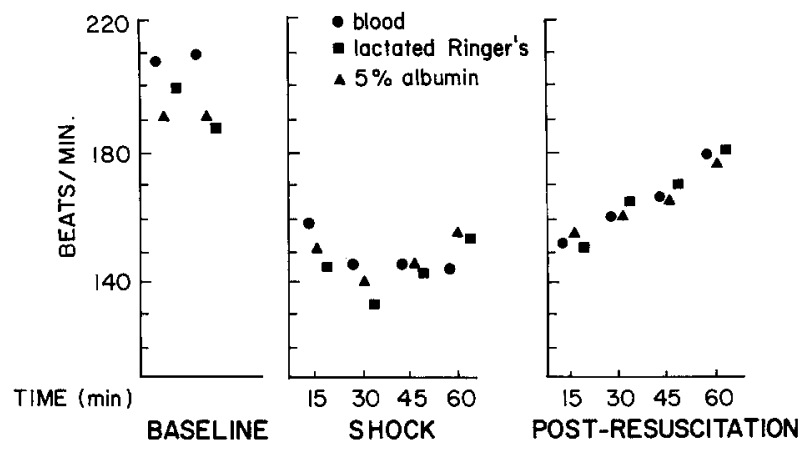

Fig. 3. Heart rate measured in 3 groups of puppies undergoing experimental resuscitation for shock.

Table 2. Hemoglobin results $(\mathrm{g} / 100 \mathrm{ml})$.

\begin{tabular}{lcccc}
\hline & $\begin{array}{c}\text { Time } \\
(\mathrm{min})\end{array}$ & $\begin{array}{l}\text { Group I } \\
(\mathrm{N}=6)\end{array}$ & $\begin{array}{l}\text { Group II } \\
(\mathrm{N}=7)\end{array}$ & $\begin{array}{l}\text { Group III } \\
(\mathrm{N}=5)\end{array}$ \\
\hline Baseline & & $10.0 \pm 1.2$ & $11.1 \pm 1.3$ & $11.9 \pm 2.0$ \\
Shock & $10.3 \pm 0.9$ & $10.7 \pm 1.4$ & $11.6 \pm 2.4$ \\
& 15 & $7.7 \pm 2.2$ & $9.1 \pm 1.6$ & $10.1 \pm 1.7$ \\
& 30 & $7.6 \pm 1.4$ & $8.6 \pm 1.2$ & $9.8 \pm 2.9$ \\
Postresuscitation & 45 & $7.9 \pm 1.0$ & $7.4 \pm 1.2$ & $8.5 \pm 1.6$ \\
& 60 & $8.6 \pm 1.6$ & $8.1 \pm 1.2$ & $8.6 \pm 1.1$ \\
& 15 & $8.7 \pm 1.6$ & $5.7 \pm 0.9$ & $6.1 \pm 2.1$ \\
& 30 & $8.2 \pm 2.0$ & $5.3 \pm 0.9$ & $4.2 \pm 2.2$ \\
& 45 & $8.5 \pm 1.6$ & $4.5 \pm 0.9$ & $6.0 \pm 1.6$ \\
& 60 & $\mathrm{NS}^{a}(p<0.05)$ & $\mathrm{S}^{b}(p<0.05)$ & $6.0 \pm 1.9$ \\
& & & & $\mathrm{~S}^{b}(p<0.05)$ \\
\hline
\end{tabular}

${ }^{a}$ NS: Not significant. ${ }^{b}$ S: Significant.

(Table 4) was noted in each group with gradual recovery toward baseline values beginning $30 \mathrm{~min}$ after resuscitation. Preshock levels were never achieved in any of the animals, and there was no significant difference among the groups.

Serum glucose levels (Fig. 5) increased significantly during the shock period, declined during resuscitation, and continued to decline to near baseline values after resuscitation. Again, there was no significant difference in the responses among the 3 groups.

Similarly, free fatty acids (FFA) (Fig. 6) increased significantly with the onset of shock to levels about 3 times normal. Following all 3 resuscitation regimens, levels gradually fell but remained insignificantly elevated above baseline, with no significant variation noted among the groups. Serum triglyceride levels (Fig. 7) remained unchanged throughout shock and resuscitation within and among the groups.

Serum cholesterol levels (Fig. 8) were stable during shock and decreased slightly postresuscitation in groups II and III. These differences were statistically significant at 15,30 , and $45 \mathrm{~min}$ postresuscitation for the lactated Ringer's group and at 30 and 45 min postresuscitation for the Ringer's lactate plus albumin group when compared to blood resuscitation.

\section{Discussion}

Our hemorrhagic shock model was effective in producing a uniform hemodynamic and metabolic response characteristic of severe shock in the experimental animals. The decreased cardiac outputs and resultant hypoperfusion were evidenced by significant lactic acidemia and metabolic acidosis. This is a response similar to that seen in adult animals and humans and reflects tissue hypoxia and anaerobic metabolism.

During the early postresuscitation period, a further rise in serum lactate and fall in blood $\mathrm{pH}$ were noted regardless of the resuscitation fluid. This sequence is consistent with the concept of "hidden acidosis" described by Litwin et al. [12]. Following restitution of more effective tissue perfusion, stagnant metabolites are "washed out" into the general circulation, which transiently worsens the acidosis already present. Following this lag period, both serum lactate and $\mathrm{pH}$ returned toward normal, but 


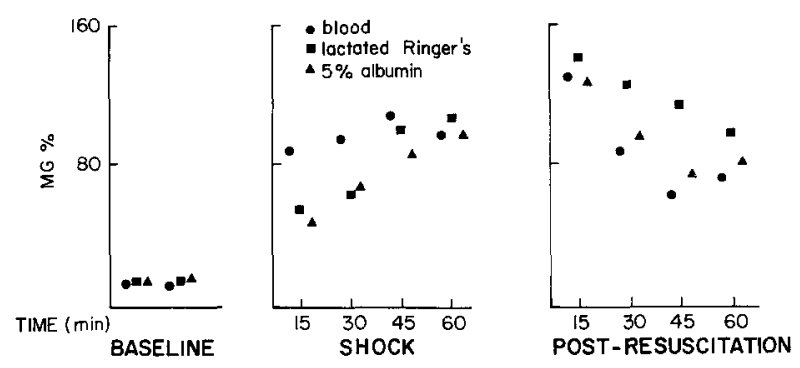

Fig. 4. Serum lactate levels measured in 3 groups of puppies undergoing experimental resuscitation for shock.

neither reached baseline values during the observation period. Although $\mathrm{pH}$ values were slightly higher in the large-volume lactated Ringer's group (II), this trend was not statistically different from the other groups. One would anticipate more rapid recovery from acidosis with the initially higher cardiac outputs seen in groups II and III. In fact, this was not seen, and can be explained by the more effective buffering qualities of whole blood [13], offsetting the better hemodynamic recovery with the asanguineous fluids. The small amount of exogenous lactate in the Ringer's solution caused no postresuscitation lactate elevation when compared to the group given blood only. This is consistent with previous studies $[14,15]$.

The initial hyperglycemia seen in the shocked puppies is a frequently reported response to hemorrhage in older dogs. This is consistent with the stimulation of glycogenolysis and gluconeogenesis by epinephrine and cortisol in shock, as well as with a relative insulin resistance noted in other studies $[16,17]$. It is not possible from our data to determine the relative contributions of each mechanism. However, a different mechanism for insulin action in carbohydrate metabolism in the very young as compared to adult animals [4] does not seem to be functioning here to any important degree. Since none of our resuscitation fluids contained added glucose, an initial drop due to dilution was expected and was seen in each group. Further gradual decrease toward baseline values is consistent with facilitated uptake following improved circulation which has also been noted in adult dogs [18].

The levels of FFA in adult shock models are variable depending on the severity of the circulatory stasis. Although it is generally accepted that elevated catecholamine levels and insulin resistance in shock cause stimulation of lipolysis in adipose stores $[19,20]$, the FFA produced will not be seen in the plasma if there is stagnant circulation. Our young animals showed a marked rise in FFA during the shock period, supporting the previously established concept that their lipolytic enzyme systems are comparable to that of the adult [21]. A decrease in hepatic clearance of FFA may also be contributing to this elevation of serum values. It is not possible for us to determine the extent to which increased production and decreased clearance contribute to the overall increase in FFA. The marked rise, however, suggests a major contribution from increased production. Following resuscitation, initial levels changed very little, suggesting that some "washout" is preventing the expected drop due to dilution. The largest initial postresuscitation change was seen in the large-volume lactated Ringer's group, but even this change was less than that predicted by dilution alone. The subsequent gradual decrease in serum values is consistent with both decreased lipolysis and hepatic oxidation, and reconversion to triglycerides, which would be expected with improved perfusion $[22,23]$.

There were no significant differences in FFA levels among the 3 groups. Although albumin is known to bind FFA, our assay was designed to break the covalent bonds between FFA and albumin, and, therefore, measured total plasma FFA. Levels seen after the $5 \%$ albumin resuscitation fluid were, as expected, statistically the same as in the other groups.

Heparinization of the animals was necessary for the chemical assay of samples. Heparin is known to stimulate lipoprotein lipase activity and to lead to the release of FFA $[24,25]$. To evaluate this mechanism in our animals, we measured 2 baseline FFA levels 15-20 min apart following heparinization, but preceding the induction of shock. Since these levels remained unchanged, subsequent increases in plasma FFA can be attributed to the shock state rather than to heparinization.

Serum triglycerides remained statistically unchanged, although there was a trend toward a small decrease in levels following resuscitation. This again is consistent with some dilution effect. Serum cholesterol levels remained unchanged during shock in all 3 groups and were unaltered following group I blood resuscitation. Serum levels in groups II and III were significantly lowered postresuscitation. This difference was expected since returned blood provides near normal levels of metabolites not found in the other fluids. This trend reached statistical significance only in the measurement of serum cholesterol. The relatively stable serum levels of cholesterol and triglycerides, the metabolism of which is controlled largely by the liver [26], probably reflect a decrease in both hepatic synthesis and metabolism secondary to decreased liver perfusion.

The metabolic response to each resuscitation regimen was similar. The relatively greater oxygen carrying capacity of blood made no critical difference at this level of hemorrhage. Although asan- 
Table 3. Bicarbonate results.

\begin{tabular}{|c|c|c|c|c|}
\hline & $\begin{array}{c}\text { Time } \\
(\min )\end{array}$ & Group I & Group II & Group III \\
\hline \multirow[t]{2}{*}{ Baseline } & & $19.7 \pm 2.1$ & $16.7 \pm 2.5$ & $19.8 \pm 3.6$ \\
\hline & & $19.9 \pm 2.2$ & $14.8 \pm 1.9$ & $18.7 \pm 3.3$ \\
\hline \multirow[t]{4}{*}{ Shock } & 15 & $12.3 \pm 4.0$ & $13.8 \pm 1.5$ & $12.9 \pm 2.3$ \\
\hline & 30 & $11.3 \pm 4.4$ & $13.2 \pm 3.3$ & $11.3 \pm 3.3$ \\
\hline & 45 & $13.7 \pm 4.6$ & $10.9 \pm 3.4$ & $10.7 \pm 2.4$ \\
\hline & 60 & $11.0 \pm 4.1$ & $10.1 \pm 3.1$ & $11.3 \pm 1.3$ \\
\hline \multirow[t]{4}{*}{ Postresuscitation } & 15 & $11.0 \pm 5.3$ & $10.8 \pm 1.9$ & $10.2 \pm 3.0$ \\
\hline & 30 & $12.5 \pm 5.8$ & $11.1 \pm 1.5$ & $11.4 \pm 3.9$ \\
\hline & 45 & $12.5 \pm 5.7$ & $13.5 \pm 1.9$ & $12.6 \pm 3.5$ \\
\hline & 60 & $13.8 \pm 5.6$ & $13.7 \pm 2.4$ & $13.4 \pm 3.4$ \\
\hline
\end{tabular}

Table 4. $\mathrm{pH}$ results.

\begin{tabular}{lllll}
\hline & $\begin{array}{l}\text { Time } \\
(\mathrm{min})\end{array}$ & Group I & Group II & Group III \\
\hline Baseline & & $7.32 \pm 0.02$ & $7.35 \pm 0.05$ & $7.33 \pm 0.04$ \\
Shock & & $7.36 \pm 0.03$ & $7.32 \pm 0.05$ & $7.28 \pm 0.07$ \\
& 15 & $7.22 \pm 0.09$ & $7.25 \pm 0.06$ & $7.20 \pm 0.04$ \\
& 30 & $7.12 \pm 0.025$ & $7.18 \pm 0.09$ & $7.15 \pm 0.04$ \\
Postresuscitation & 45 & $7.10 \pm 0.25$ & $7.14 \pm 0.09$ & $7.12 \pm 0.03$ \\
& 60 & $7.15 \pm 0.14$ & $7.09 \pm 0.09$ & $7.08 \pm 0.09$ \\
& 15 & $7.06 \pm 0.22$ & $7.14 \pm 0.10$ & $7.08 \pm 0.06$ \\
& 30 & $7.09 \pm 0.20$ & $7.21 \pm 0.10$ & $7.06 \pm 0.12$ \\
& 45 & $7.13 \pm 0.21$ & $7.24 \pm 0.09$ & $7.18 \pm 0.09$ \\
\hline
\end{tabular}
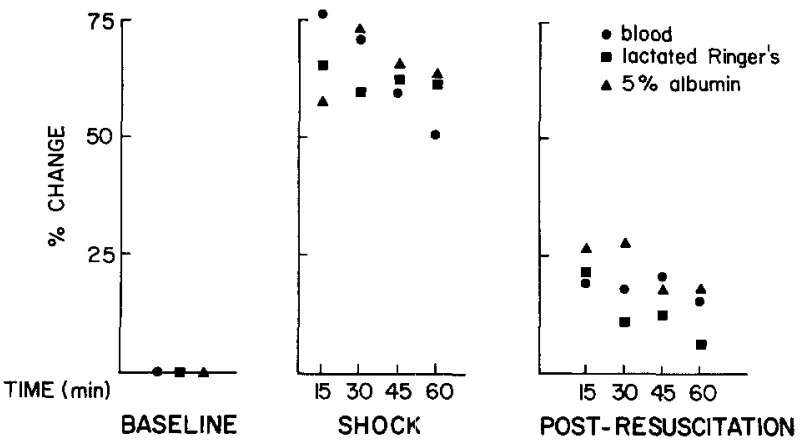

Fig. 5. Serum glucose levels measured in 3 groups of puppies undergoing experimental resuscitation for shock.

guineous fluids caused a better initial postresuscitation cardiac output, this did not alter the metabolic response in this model. Similarly, the presence of albumin did not measurably change the blood levels of the various metabolites. Despite the experimental animal's immaturity, its metabolic responses to hemorrhagic shock were very similar to those seen in adult animals.

Healthy mongrel puppies were used in this study rather than colony-bred animals because of the large cost of colony-bred puppies. All animals were screened and considered healthy and stable by our veterinarians prior to the experiment. A recent study from our laboratory has shown significant differences between colony-bred puppies and unscreened random-source puppies in their response to septic shock [27].

\section{Résumé}

Les états de choc s'accompagnent d'une mortalité élevée chez les enfants. En ayant recours à l'expérimentation chez le chiot, les auteurs ont mesuré les modifications métaboliques initiales en réponse au choc hémoragique et à sa correction par 3 agents différents : sang complet $(1: 1)$, solution de Ringer ( $3: 1)$ et solution de Ringer enrichie de $5 \%$ d'albumine. Malgré la nature immature des enzymes du chiot, du système cardio-vasculaire et du système nerveux, les réponses furent identiques à celles observées chez le chien adulte.

Le glucose et les acides gras libres s'élevèrent au cours du choc et s'abaissèrent lors de la réanimation dès que le débit cardiaque revint à la normale. Les niveaux du lactate sanguin s'élevèrent de la 


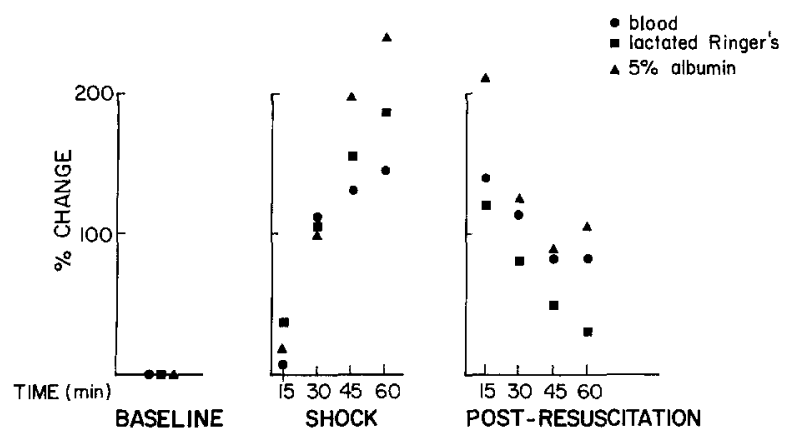

Fig. 6. Free fatty acid measurements taken in 3 groups of puppies undergoing experimental resuscitation for shock.

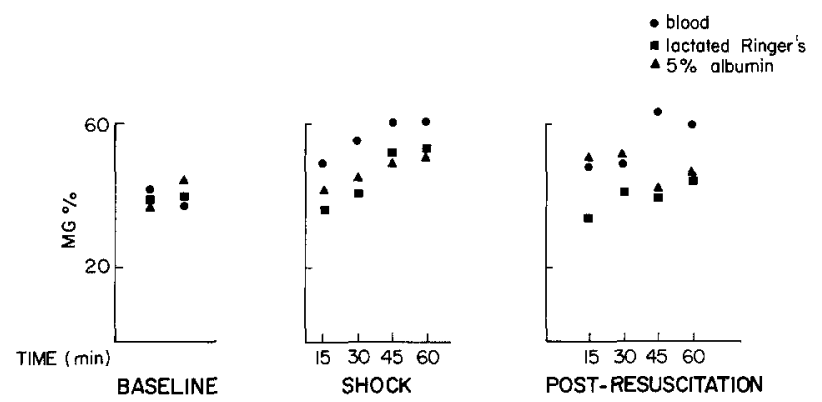

Fig. 7. Serum triglyceride levels measured in 3 groups of puppies undergoing experimental resuscitation for shock.

même manière mais l'élévation continua pendant une courte période après la réanimation, cependant que le $\mathrm{pH}$ s'abaissait, démasquant une "acidose cachée". Les taux des triglycérides et du cholestérol furent seulement discrètement altérés.

Les réponses métaboliques étudiées en fonction des 3 méthodes de réanimation furent identiques.

Cette étude suggère que le chiot répond de la même façon que le chien adulte au choc hémorragique et que les 3 méthodes de réanimation employant chacune des agents différents ont une efficacité identique.

\section{Resumen}

Los estados shock mantienen una elevada mortalidad en los grupos de edad pediátrica. Utilizando un modelo de shock en cachorros, se determinó la respuesta metabólica inicial al shock hemorrágico y a tres diferentes regimenes de resucitación: sangre total 1:1 (reemplazo: pérdida), lactato de Ringer 3:1, y albúmina al 5\% en lactato de Ringer 1:1. A pesar de la naturaleza inmadura de los sistemas enzimático, cardiovascular y nervioso del cachorro, las respuestas fueron muy similares a las observadas en animales adultos. La glucosa sérica y los ácidos grasos libres ascendieron durante el shock y declinarion en la medida que el débito cardiaco

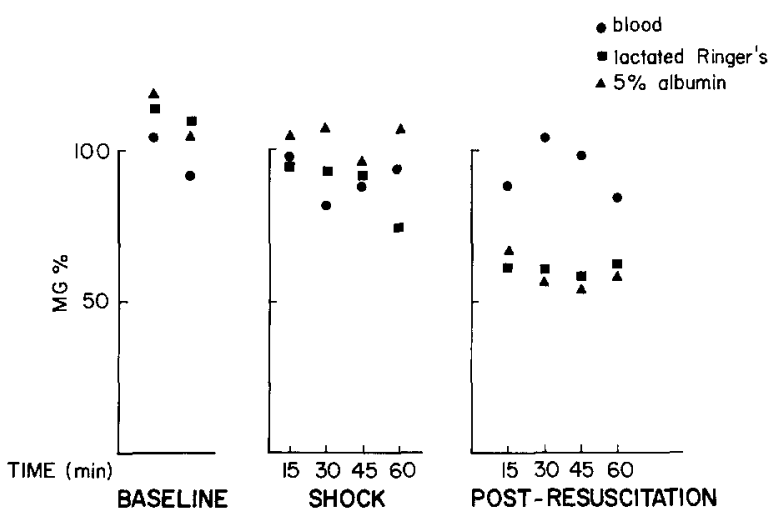

Fig. 8. Serum cholesterol measurements in 3 groups of puppies undergoing experimental resuscitation for shock.

retornaba a lo normal. Los niveles de lactato sérico ascendieron en forma similar, pero continuaron su ascenso por un corto periodo de tiempo después de la resucitación, encontrándose asociados con una caida adicional del $\mathrm{pH}$ consistente con "acidosis oculta". Sólo se presentaron cambios leves en los niveles de triglicéridos y colesterol. Las respuestas metabólicas observadas en cada uno de los tres protocolos de resucitación fueron similares. Este estudio sugiere que el animal inmaduro responde al shock hemorrágico de manera similar al adulto. La mejor respuesta hemodinámica inicial a la resucitación con altos volúmenes de lactato de Ringer o con lactato de Ringer con albúmina al 5\%, fue compensada con una mejor capacidad de amortiguación observada en la resucitación con sangre. Los tres regimenes fueron igualmente eficaces en lograr la recuperación metabólica inicial en este modelo experimental de shock hemorrágico.

\section{References}

1. Smith, C.A.: The Physiology of the Newborn Infant, 2nd ed. Springfield, Ill. Charles C Thomas, 1951, p. 222

2. Boyd, E.M.: Lipid composition of blood in newborn infants. Am. J. Dis. Child. 52:1319, 1936

3. Kaizer, A.D., Gray, M.S.: Blood lipids in children with scarlet fever and rheumatic disease. Am. J. Dis. Child. 47:9, 1934

4. Schiff, D.: Carbohydrate metabolism in the newborn. Letter to the editor. Lancet $1: 475,1968$

5. Kaye, R., Davidson, M.H., Williams, M.L., Kumagai, M., Picou, D.M.: The response of blood glucose, ketones and plasma nonesterified fatty acids to fasting and epinephrine injection in infants and children. J. Pediatr. 59:836, 1961

6. Strodel, W.E., Callahan, M., Weintraub, W.H., Coran, A.C.: The effect of various resuscitation regimens on hemorrhagic shock in puppies. J. Pediatr. Surg. 12:809, 1977 
7. Calbiochem: Calbiochem rapid lactate stat-pack. La Jolla, California

8. Dow Chemical: Glucose determination. Dow Diagnostics, Indianapolis, Indiana

9. Dow Chemical: Triglycerides determination. Dow Diagnostics, Indianapolis, Indiana

10. Dow Chemical: Cholesterol determination. Dow Diagnostics, Indianapolis, Indiana

11. Dole, V.P., Meinertz, H.: Microdetermination of long-chain fatty acids in plasma and tissues. J. Biol. Chem. 235:2595, 1960

12. Litwin, M.S., Bergentz, S.E., Carsten, A., Gelin, L.E., Rudenstam, C.M., Soderholm, B.: Hidden acidosis following intravascular red blood cell aggregation in dogs: Effects of high and low viscosity dextran. Ann. Surg. 161:532, 1965

13. Ansel, H.C.: Change in $\mathrm{pH}$ of infusion solutions upon mixing with blood. Letter to the editor. JAMA 218:1052, 1971

14. Coran, A.G., Ballantine, T.V., Horwitz, D.L., Herman, C.M.: The effect of crystalloid resuscitation in hemorrhagic shock on acid-base balance: A comparison between normal saline and Ringer's lactate solutions. Surgery 69:874, 1971

15. Trinkle, J.K., Rush, B.F., Eiseman, B.: Metabolism of lactate following major blood loss. Surgery 63:782, 1968

16. Stoner, H.B., Threlfall, C.J.: The Biochemical Response to Injury, Springfield, Ill., Charles C Thomas, 1960

17. Drucker, W.R., Dekiewiet, J.C.: Glucose uptake by diaphragms from rats subjected to hemorrhagic shock. Am. J. Physiol. 206:317, 1964

18. Vigas, M., Hetenyi, G.J., Haist, R.E.: Glucose metabolism in post-hemorrhagic shock in the dog. J. Trauma $11: 615,1971$

\section{Invited Commentary}

\author{
Harry M. Shizgal, M.D.
}

McGill University, Montreal, Canada

At the turn of the century, shock was defined by the presence of an abnormally decreased blood pressure and, as a result, the treatment of shock was directed at correcting the blood pressure. Because this approach often proved unsuccessful, the shock state was redefined as an abnormally decreased cardiac output and treatment was based on the restoration of cardiac output. A new definition of shock was necessitated by the demonstration of high-output shock, i.e., a metabolic and clinical state consistent with shock in the presence of an elevated cardiac output.

The present study is, therefore, important in that it emphasizes that the successful management of
19. Kovach, A., Rosell, S., Sandor, P.: Influence of adrenergic p-receptor activity on blood flow and free fatty acid release in canine subcutaneous adipose tissue during hemorrhagic shock. Naunyn-Schmiedelberg's Arch. Pharmak. 268:140, 1971

20. Ballard, K., Cobb, C., Rosell, S.: Vascular and lipolytic responses in canine subcutaneous adipose tissue following infusion of catecholamines. Acta Physiol. Scand. 81:246, 1971

21. Coran, A.G., Nesbakkan, R.: The metabolism of intravenously administered fat in adult and newborn dogs. Surgery 66:922, 1969

22. Armstrong, D.T., Steele, R., Altszuler, N., Dunn, A., Bishop, J.S., DeBodo, R.C.: Regulation of plasma free fatty acid turnover. Am. J. Physiol. 201:9, 1961

23. Mays, E.T.: The effect of surgical stress on plasma free fatty acids. J. Surg. Res. 10:315, 1970

24. Baker, R.M., Schreiner, B.F., Schalch, D.S., Greene, W.A.: Effect of extended infusion of a low dose of heparin on plasma levels. J. Clin. Endocrinol. Metab. 30:670, 1970

25. Ballard, K., Fredholm, B.B., Meng, H.C., Rosell, S.: Heparin-induced release of lipase activity from perfused canine subcutaneous adipose tissue. Proc. Soc. Exp. Biol. Med. 137:1490, 1971

26. Gillman, J., Gilbert, C.: Some aspects of the endocrine control of serum lipids, blood ketones and blood sugar in fed and fasted baboons, and of the mechanism of fuel control in fasting, with special reference to diabetes and lipaemia. Exp. Med. Surg. $28: 45,1970$

27. Coran, A.G., Drongowski, R.A., Wesley, J.R.: Septic shock in colony-bred puppies versus randomsource puppies. (In press)

shock requires the treatment of both the cardiovascular dysfunction and the metabolic abnormalities. Similarly, it is important to characterize the hemodynamic, metabolic, and endocrine complications of shock in the pediatric age group, as opposed to the adult, as important differences may exist. However, caution must be exerted when interpreting the data presented in this study, as important differences exist between humans and the dog. In the $\mathrm{dog}$, the liver is the principal shock organ. Thus, shock in the dog is characterized by hepatic vasoconstriction, resulting in the pooling of blood within the splanchnic circulation. This is the principal cause of death with the Wigger's shock model, an adaptation of which the authors have employed in this study. The continued pooling of blood within the splanchnic circulation is probably the mechanism responsible for the continually decreasing cardiac output that occurred during the entire postresuscitation period with all 3 groups (see Fig. 2). Had observations been carried out during the resuscitation period for longer than 1 hour, I would have 